\title{
Passwords
}

Volume 12 | Issue 2

Article 17

6-4-2012

\section{Bella vista}

Natalie Dunn

nadunn@students.pitzer.edu

Follow this and additional works at: http://scholarship.claremont.edu/passwords

Part of the Creative Writing Commons

\section{Recommended Citation}

Dunn, Natalie (2012) "Bella vista," Passwords: Vol. 12: Iss. 2, Article 17. DOI: 10.5642/passwrd.20121202.17

Available at: http://scholarship.claremont.edu/passwords/vol12/iss2/17

This Poetry is brought to you for free and open access by the Journals at Claremont at Scholarship @ Claremont. It has been accepted for inclusion in

Passwords by an authorized administrator of Scholarship@ Claremont. For more information, please contact scholarship@cuc.claremont.edu. 


\section{Bella vista}

\section{Natalie Dunn}

His poems of love bring you to his house of collections sea-glass bottles

little ancient lakes spill puddles of light onto the floor

Neruda's blue-green ghost

playful and sad

is folded into a parched landscape

a piece of lapis lazuli concealed in the brick wall

a horse from India robed with round mirrors

Russian nesting dolls still in place

small things - perpetual

repetitive

true

remind you of a loyalty you have not found yet

he knew of smallness

whispered about it to you in breaths between words

and you feel loss because he introduced the moon to you

he taught you to live like seawater

(Loose and alone)

Salmon fishing - your father

Coral-red flesh swims

He catches it (in a whisper)

$\mathrm{He}$ and it become a handful of earth and sea

Slender moon

Stay in place-small thing 